\title{
Phytoprotection
}

\section{Insect parasitoids : a Canadian perspective on their use for biological control of forest insect pests}

\section{S.M. Smith}

Volume 74, numéro 1, 1993

URI : https://id.erudit.org/iderudit/706036ar

DOI : https://doi.org/10.7202/706036ar

Aller au sommaire du numéro

Éditeur(s)

Société de protection des plantes du Québec (SPPQ)l

ISSN

0031-9511 (imprimé)

1710-1603 (numérique)

Découvrir la revue

Citer cet article

Smith, S. (1993). Insect parasitoids : a Canadian perspective on their use for biological control of forest insect pests. Phytoprotection, 74(1), 51-67. https://doi.org/10.7202/706036ar
Résumé de l'article

Nous présentons un survol des programmes de lutte biologique envers les insectes forestiers en mettant l'accent sur des cas canadiens. Ces travaux de recherche sont examinés dans le contexte de la conservation, de l'introduction et de l'augmentation (par manipulation de l'environnement et lâchers inoculants et massifs) des ennemis naturels, et plus spécifiquement des parasitoïdes. Historiquement les études ont porté sur l'introduction de parasitoïdes exotiques pour la lutte aux insectes nuisibles introduits, un certain nombre de ces travaux ayant été fructueux. Des travaux plus récents ont consisté en des lâchers inoculants et massifs de parasitoïdes contre des insectes indigènes afin d'établir de nouvelles relations hôte-parasitoïde dans le but de réduire les populations d'insectes indésirables. Ces nouvelles techniques n'ont démontré que des résultats limités et les recherches se poursuivent dans cette voie. Les stratégies actuelles d'utilisation d'ennemis naturels sont le lâcher massif d'espèces indigènes contre des espèces nuisibles indigènes et la conservation des parasitoides indigènes par des applications sélectives d'herbicides et la gestion des forêts. Les prochaines avenues pour les programmes de lutte biologique incluront ces approches en plaçant l'accent sur les biotechnologies et la sélection génétique ou la manipulation de lignées recherchées pour les lâchers. Des études écologiques continues seront essentielles à l'obtention d'une meilleure compréhension des interactions entre ces parasitoïdes sélectionnés et les données forêt-arbre qui influenceront leur succès (interaction tritrophique). Ces données, à savoir la vigueur de l'arbre (résistance aux insectes), distribution spatiale et diversité, seront aussi visées pour la sélection afin d'améliorer l'impact des ennemis naturels des parasites dans l'environnement forestier.
Ce document est protégé par la loi sur le droit d'auteur. L’utilisation des services d’Érudit (y compris la reproduction) est assujettie à sa politique d'utilisation que vous pouvez consulter en ligne.

https://apropos.erudit.org/fr/usagers/politique-dutilisation/ 


\title{
Insect parasitoids: a Canadian perspective on their use for biological control of forest insect pests
}

\author{
Sandy M. Smith ${ }^{1}$
}

Received 1992-11-18; accepted 1993-05-18

An overview of biological control programs against forest insect pests is presented with emphasis on Canadian case histories. The work is examined in the context of conservation, introduction, and augmentation (environmental manipulation and inoculative and inundative release) of insect natural enemies, specifically parasitoids. Historically, studies have concentrated on introductions of exotic parasitoids for control of introduced pests where a number of successes have been recorded. More recent work has entailed inoculative and inundative releases of parasitoids against native pests in an attempt to establish new host-parasitoid relationships to reduce pest populations. These have had limited success and are still being explored by Canadian researchers. Current strategies for using natural enemies are inundative release of native species against native pests and conservation of native parasitoids through selective insecticide timing and forest manipulation. Future directions in biological control programs will include these approaches with increased emphasis on biotechnology and the genetic selection or manipulation of 'desired strains' for release. Continued ecological studies will be essential to ensure a more complete understanding of the interaction between these 'selected parasitoids' and the forest/tree parameters which will influence their success (tri-trophic interactions). These parameters, such as tree vigour (pest resistance), spatial distribution and diversity, will also be targeted for selection to improve the effect of insect natural enemies in the forest environment.

Smith, S.M. 1993. Les insectes parasitoïdes: perspective canadienne de leur utilisation pour la lutte biologique en milieu forestier. PHYTOPROTECTION 74: 51-67.

Nous présentons un survol des programmes de lutte biologique envers les insectes forestiers en mettant l'accent sur des cas canadiens. Ces travaux de recherche sont examinés dans le contexte de la conservation, de l'introduction et de l'augmentation (par manipulation de l'environnement et lâchers inoculants et massifs) des ennemis naturels, et plus spécifiquement des parasitoïdes. Historiquement les études ont porté sur l'introduction de parasitoïdes exotiques pour la lutte aux insectes nuisibles introduits, un certain nombre de ces travaux ayant été fructueux. Des travaux plus récents ont consisté en des lâchers inoculants et massifs de parasitoïdes contre des insectes indigènes afin d'établir de nouvelles relations hôte-parasitoïde dans le but de réduire les populations d'insectes indésirables. Ces nouvelles techniques n'ont démontré que des résultats limités et les recherches se poursuivent dans cette voie. Les stratégies actuelles d'utilisation d'ennemis naturels sont le lâcher massif d'espèces indigènes contre des espèces nuisibles indigènes et la conservation des

1. Faculty of Forestry, 33 Willcocks St., University of Toronto, Toronto, Ontario, Canada M5S 3B3 
parasitoïdes indigènes par des applications sélectives d'herbicides et la gestion des forêts. Les prochaines avenues pour les programmes de lutte biologique incluront ces approches en plaçant l'accent sur les biotechnologies et la sélection génétique ou la manipulation de lignées recherchées pour les lâchers. Des études écologiques continues seront essentielles à l'obtention d'une meilleure compréhension des interactions entre ces parasitoïdes sélectionnés et les données forêt-arbre qui influenceront leur succès (interaction tritrophique). Ces données, à savoir la vigueur de l'arbre (résistance aux insectes), distribution spatiale et diversité, seront aussi visées pour la sélection afin d'améliorer l'impact des ennemis naturels des parasites dans l'environnement forestier.

Despite strong support for biological control at the turn of the century, in recent years there has been considerable controversy surrounding the use of insect parasitoids for biological control of insect pests. While this approach to pest control is perceived as environmentally acceptable, the success of biological control attempts has been questioned since the 1950's by a wide range of people involved either directly with the research aspect or indirectly at the political level. Uncertainty has surrounded both the degree of success achieved and the costbenefit relationship for such enterprises. As an entomologist who has worked in the area of inundative parasitoid release for over 10 years, I have also questioned the potential for successfully integrating my work into practical forest operations, considering the time and costs involved and the level of control that can be achieved.

In the following review, I will discuss the record of attempts made in biological control of forest insect pests with particular emphasis on Canadian case histories. Despite the controversy, the literature suggests that we have been very successful at suppressing forest insect pests using insect parasitoids, and that in fact, Canada is a world leader in this area (Hulme and Kelleher 1984; Pschorn-Walcher 1977). The relatively high number of successes that we have been able to achieve reflects our emphasis on forestry (Dahlsten and Mills 1990) where the number of successes can be directly attributed to the number of attempts. This work will be discussed in the context of the approach taken and the current state- of-the-art with thoughts on future directions. It is hoped that the positive results of the past will provide incentive and groundwork to continue studies in the future.

\section{TERMINOLOGY IN BIOLOGICAL CONTROL}

The field of biological control is broad and thus, it is essential to start this discussion with some specific definitions as to the scope of biological control, the difference between biocontrol agents, the concept of parasitoid guilds, and new versus old host associations.

Jutsum (1988) provides an overview of the biological control spectrum from the perspective of plant protection. He includes components ranging from biotic agents to behaviour-modifying chemicals and specifically describes the biotic agents as BCA's (biological control agents). The use of BCA's (parasitoids, predators, and pathogens) is analogous to the earlier definition of biological control presented by DeBach (1964), "the action of parasites, predators, and pathogens in maintaining another organism's population density at a lower average than would occur in their absence" and is the one with which the present paper will deal.

Emphasis in forestry has been on the use of parasitoids, predators, and pathogens of insect pests (Hulme and Kelleher 1984). In most cases, pathogens are single-celled microorganisms which live inside the insect in large numbers. They 
may or may not kill the host, but generally cause debilitation and reduced growth and reproduction which has implications for the pest's population dynamics. Although there have been several major successes using pathogens against forest pests (e.g. use of the bacterium, Bacillus thuringiensis (Berliner), Bt, and entomopathogenic viruses against the gypsy moth, [Lymantria dispar (L.)] [Lepidoptera: Lymantriidae] and Douglas fir tussock moth [Orgyia pseudotsugata (McDunnough)] [Lepidoptera: Lymantriidae](Hulme and Kelleher 1984), my intention is to limit further discussion here to non-microscopic natural enemies.

The present paper deals with insects that eat other insects. This includes parasitoids and predators, both of which are multi-cellular, free-living (at least at one stage) and always kill their host. Individual predators consume a large number of hosts or prey and are often less discriminating in prey selection than parasitoids. While insect predators such as ants, coccinelids, carabids, and lacewings are widely recognized components in ecological webs and some of the earliest records of biocontrol make reference to them (Hulme 1988), there are relatively few examples of predaceous insects being used in forestry for biological pest control. Thus, in the following discussion, emphasis will be placed on parasitoids although reference will be made to predators where appropriate.

Unlike true parasites, parasitoids do not live in symbiosis with their individual host but instead act as specialized predators, always killing their host (usually one per parasitoid) (Anonymous 1983). The immature parasitoid consumes the host as it develops, either internally or externally and the adult stage is usually free-living. Askew (1971) estimated that over 200000 species of the order Hymenoptera were parasitoids; this represents almost $10 \%$ of all animal species. Parasitoid life-styles are found in 87 families from five insect orders (Sweetman 1936) with one genus in Hymenoptera alone accounting for almost 1000 species of parasitoids (Waage and Hassell 1982).

The relationship of parasitoids to their hosts is often complex with many different species attacking a single host spe- cies. In some cases, the parasitoids may compete with each other for the same host stage (e.g. larva); in other cases, different parasitoid species selectively attack different stages of the host (e.g. egg, $1^{\text {st }}-6^{\text {th }}$ instar larva or pupa). The complex of parasitoid species attacking a single host is referred to as a parasitoid guild. Parasitoid guilds are the rule rather than the exception in the insect world providing structured communities with life-history and habitat stability (Mills 1983).

Considerable information is available on parasitoid guilds in forest insects. For example, the spruce budworm, Choristoneura fumiferana (Clemens) [Lepidoptera: Tortricidae], is known to have approximately 70 species of parasitoids associated with all stages of its development; egg parasitism $(10 \%)$, young larvae $(30-$ $45 \%)$, old larvae $(10-36 \%)$, and pupae (5$15 \%)$ and parasitism by late larval species is considered to regulate budworm populations through a delayed densitydependent effect (Mills 1983). The composition of these parasitoid guilds is not static but has been shown to vary according to ecological factors including host density (Nealis 1991a). Often one of the parasitoid species is considered to be the key factor in regulating the host population although that key species will vary from region to region (Flanders 1971; Thompson 1930).

Associations between parasitoids and hosts which are typified by these guilds can be classified as either old or new. Old associations are considered those which have a long evolutionary history; the parasitoid/host species have evolved together historically. New associations are those used by Hokkanen and Pimentel (1984) to describe situations where previously isolated parasitoids and hosts have been brought together either through the introduction of the host (non-native pests accidentally introduced from outside North America) or the parasitoid (exotic parasitoids imported from outside North America to be used against native pests). The widest shift in a new association which has been recorded is that for an egg parasitoid, Telenomus spp. which successfully attacked a host from another subfamily in Geometridae (Drooz et al. 1977). 


\section{APPROACHES TO IMPLEMENTING BIOLOGICAL CONTROL}

There are several different approaches for using parasitoids and predators in the field and some confusion exists as to how these should be classified. In general, biological control can be implemented as either: 1) conservation; 2 ) introduction; or 3) augmentation (Beirne 1967; Mills 1990; Nordlund 1984). When dealing with specific cases, however, the distinction between these approaches is blurry and often overlaps. Beirne (1967) suggested that these categories were appropriate and should be considered in this exact sequence in all integrated pest management programs. Those attributes that contribute to a good natural enemy have been outlined by several authors (Huffaker and Kennett 1969; Luck 1990; Mackauer 1976; Quednau 1990).

\section{Conservation}

The conservation of parasitoids and predators is a poorly studied aspect of biological control, perhaps more so in forestry than in agricultural systems. By definition, it is any activity which prevents a reduction in natural enemies and thus, seeks to maintain their levels in a target area (Mills 1990). It is perhaps the least disruptive of the approaches to biological control because it does not attempt to intervene in the ecology of the system, simply to maintain it. There are two aspects to maintaining parasitoid populations; habitat conditions and insecticide selectivity.

\section{Habitat conditions}

Inferences on the effect of habitat conditions in forests can be taken from attempts to develop polycultures in agriculture. Intercropping, deliberate mixing of more than one plant species in a given area, has been conducted in a few agricultural systems with generally positive, if not somewhat mixed, results (Altieri and Whitcomb 1979; Altieri et al. 1977; Herzog and Funderburk 1985). Beirne (1967) noted that intercropping was simply proper integrated pest management and Mills (1990) suggested this approach for forest systems. Unfortunately, even less work on the effect of plant diversity and natural enemy populations has been conducted in forestry, where the system already tends to be more diverse than in agriculture.

Syme (1977) found that higher populations of the larval parasitoid, Orgilus obscurator (Nees) [Hymenoptera: Eraconidae], could be associated with the presence of wild carrot (Daucus carota L.) and that this could have an impact on its host, the European pine shoot moth [Rhyacionia buoliana (Schiff.)] 'Lepidoptera: Olethreutidae]. Recent unpublished work by Bradette and Oliveira (personal communication) at the Université du Québec in Montréal suggests that increased plant diversity and alternate wild flower sources have no detectable effect on populations of the larval parasitoid, Actia interrupta Curr. [Diptera: Tachinidae] attacking the spruce budworm.

From life table data, the impact of natural enemies is known to be high for a number of important forest pests (Nealis 1991b). Perhaps the best that can be done in the area of habitat condition at this stage is to identify those areas where a high abundance of natural enemies is associated with a pest insect and try to relate that activity to stand diversity.

\section{Insecticide selectivity}

The second aspect to conservation is that of insecticide use and selectivity (Mills 1990). This can be considered from both the physiological and ecological perspective (Hull and Beers 1985). Physiological refers to the type of insecticide used and the relative resistance of parasitoids to such insecticides while ecological refers to the timing, placement, dosage, and technique of applying the insecticide. More research has been conducted in this area in agriculture because of the more intensive use of insecticides than in forestry, however, a few important examples are available.

Both with the European spruce sawfly [Gilpinia hercyniae (Hartig)] [Hymenoptera: Diprionidae] and the hemlock scale [Abgrallaspis ithacae (Ferris)] [Homoptera: Diaspididae], it has been shown that increased use of insecticides results in higher populations of these pests as a 
result of reduced activity by natural enemies (McClure 1978; Nielson et al. 1971). The recent shift towards using more selective microbial insecticides such as Bacillus thuringiensis kurstakii (Berliner) $(B t)$ to suppress forest insects in Canada is one method to reduce the impact of these treatments on parasitoid populations. While the main reason for this shift has been public pressure, the effect is essentially to select an insecticide which will be less damaging to the natural enemy than to the pest (Hassan et al. 1987; Nealis 1991b).

Research has also been conducted into the optimal timing of insecticide applications for minimal effects on natural enemies. Nealis and van Frankenhuyzen (1990) have shown that higher levels of parasitism of young spruce budworm larvae can be achieved if $B t$ is applied against the host larva in its $4^{\text {th }}$ rather than $3^{\text {rd }}$ instar. This delay of approximately one week in the field provides sufficient time for the parasitoid, Apanteles fumiferanaeViereck [Hymenoptera: Braconidae], to emerge from the host and thus, avoid indirect mortality due to the insecticide application.

More recent research in agricultural systems is directed at developing insecticide resistance in the parasitoid or predator. This can be achieved either through traditional breeding programs in the laboratory or by utilizing the techniques of molecular engineering (Beckendorf and Hoy 1985; Rosenheim and Hoy 1988). To date, this has not been attempted in forestry because the shift to less toxic compounds and only one to two applications per year, means that there is relatively little insecticide pressure.

\section{Introduction}

The introduction of parasitoids and predators is the traditional approach to biological control and is often called the 'classical approach' because once established, it is self-sustaining (Mills 1990). From a North American perspective, it was the first approach used, being primarily directed against pests introduced accidentally from Europe during colonization. Indeed, the majority of records show this approach is being used to reestablish old associations of exotic North
American pests with the importation of European natural enemies (PschornWalcher 1977). Importations in the opposite direction (where a native parasitoid from North America was introduced to Europe) show only one unsuccessful example in an attempt to control the European pine shoot moth.

Worldwide, about 4300 species of parasitoids and predators have been introduced to control 300 pest species in agricultural and forestry systems (Waage and Greathead 1988); 223 parasitoids against 120 pests in the USA alone (Ryan 1987). The success rate of these introductions has been the source of considerable controversy, however, it is generally agreed that of these attempts, $34-40 \%$ have become established (Hall and Ehler 1979; Waage and Greathead 1988) and approximately $16 \%$ are considered to be successful in terms of control (Myers et al. 1989).

In Canada, introducing parasitoids has been the primary approach to biological control. Between the years 1910 and 1980, approximately 135 natural enemies have been imported against 57 pests; 12 of these were considered successes (Hulme and Kelleher 1984; McGugan and Coppel 1962; Reeks and Cameron 1971). The first successful introduction was that of the parasitoid Mesoleius tenthredinis Morl. [Hymenoptera: Ichneumonidae] against the larch sawfly [Pristiphora erichsonii (Hartig)] [Hymenoptera: Tenthredinidae] in 1910-1913. Hymenoptera has been by far the most important order accounting for $72 \%$ of the introductions. Over this period, only one incidence of resistance developing in the host was documented for the larch sawfly.

Hulme (1988) considered that 8 out of the 11 pests studied over the years in Canada were successfully controlled through attempts at biological control although these included the use of pathogens as well as introductions of parasitoids. Nealis and Wallace (1991) identified six successful attempts at introducing parasitoids to control forest insects including the European spruce sawfly, larch casebearer [Coleophora laricella (Hubner)] [Lepidoptera: Coleophoridae], larch sawfly, satin moth [Leucoma salicis (L.)] [Lepidoptera: Lymantriidae], 
winter moth [Operophtera brumata (L.)] [Lepidoptera: Geometridae], and European pine shoot moth. The success of these programs has been well documented through a series of $C A B$ publications (Hulme and Kelleher 1984; McGugan and Coppel 1962; Reeks and Cameron 1971) and for individual cases on the winter moth (Caltagirone 1981; Murdoch et al. 1985; Roland 1988), larch sawfly (Graham 1931), and European pine shoot moth (Juillet 1960; Miller 1967; Pointing and Green 1962). The cost:benefit relationship for the program against the European pine shoot moth was estimated at $\$ 300$ 000 : $\$ \$ 6$ million $(1: 75)$ and that for the winter moth at $\$ 160$ 000:>\$12 million (1:20). Both have provided higher returns than that cited for agricultural systems in Australia at 1:10 (Pschorn-Walcher 1977) but similar to those from Europe at 1:30 (van Lenteren 1983).

A relatively recent Canadian success has been the introduction of a parasitoid for control of the Mountain-ash sawfly [Pristiphora geniculata (Hartig)] [Hymenoptera: Tenthredinidae]. This pest was accidentally introduced into North America in 1926 moving into Canada in 1934 (Quednau 1990). Its effect is localized and primarily of aesthetic value, occasionally causing complete defoliation of mountain ash. In 1976-1978, 1300 female Olesicampe geniculatae Quednau \& Lim [Hymenoptera: Ichneumonidae] from Europe were released near Québec City. Samples collected during 1984 showed that this parasitoid had spread throughout the province at a rate of $50 \mathrm{~km} \mathrm{yr}^{-1}$. At the time of the report (Quednau 1990), parasitism levels of the sawfly were $6-94 \%$ with no major infestations recorded in Québec during the last seven years.

Despite the encouraging rate of success with introductions of parasitoids, a number of significant failures can be documented against major pest species. In fact, most of the insects that still remain a problem in Canadian forestry have been subject to parasitoid introductions, but have not been controlled either because the parasitoids have not established or their establishment has not resulted in economic reductions of the pest.

Noteworthy failures with introductions have been against the spruce budworm, gypsy moth, bark beetles, and conifer adelgids (Hulme and Kelleher 1984; McGugan and Coppel 1962; Reeks and Cameron 1971). Between 1944 and 1973, 18 species of parasitoids were introduced to eastern Canada from western Canada, Europe and Japan for control of the spruce budworm. One of the species from Japan was encapsulated while the remaining failed to establish. In 1963, ants were introduced for budworm control from western into eastern Canacla but failed to reduce populations (Youngs 1983). This was followed by introductions of ants from Italy to Québec in 1973 which reduced defoliation by $20 \%$, but not below economic levels (Finnegan 1975). Research in the last 10 years has shifted to improving the application of Bt and inundative releases of parasitoids for annual suppression of spruce budworm.

Over the past 100 years, 78 species of parasitoids have been introduced from Europe for control of the gypsy moth, an exotic pest of deciduous hardwoods in North America (Reardon 1981; Sawyer 1990). Ten of these species have become established in the USA of which seven have moved into Canada with the pest (Fuester et al. 1988; Nealis and Wallace 1991). Native parasitoids have also established on the gypsy moth, but all these factors have failed to prevent damaging outbreaks. The gypsy moth still remains one of the major forest pests in North America.

Past attempts at establishing parasitoids against the conifer adelgids [e.g. balsam woolly adelgid, Adelges piceae (Ratz.)] [Homoptera: Phylloxeridae] have also met with failure. Between 1930-1960, 29 predators (primarily Coleoptera and Diptera) were released in the USA and Canada with only slight control (Mills 1990). While worldwide success in controlling Homopteran pests is unusually high (Greathead 1989), this has not been the case in Canadian forestry.

Bark beetles, such as the Mountain pine beetle [Dendroctonous ponderosae (Hopkins)] [Coleoptera: Scolytidae] and the southern pine beetle [Dendroctonous frontalis (Zimmerman)] [Coleoptera: Scolytidae], also have been the subject of limited investigations for biological control through parasitoid introductions 
(Miller et al. 1987). As early as the turn of the century (1890) through to 1976 , sporadic attempts at introductions against the southern pine beetle failed. Information from the Commonwealth of Independent States (formerly the USSR) suggests that clerid beetles may be efficient predators for controlling Dendroctonous species at endemic levels, but to date, insufficient numbers have been released in North America to establish their potential (Miller et al. 1987).

Reasons for failure in introductions are being continuously examined in an attempt to develop the most appropriate strategy. Pschorn-Walcher (1977) cited a number of characteristics of failed attempts; too few numbers released, asynchrony between host and parasitoid, competition with native parasitoids, wrong species released, lack of alternate hosts for survival and overwintering, presence of hyperparasitoids, host resistance and procedural errors. Turnock et al. (1976) suggested that classical biocontrol was difficult in forestry because the relatively simple conifer ecosystems led to widely unstable pest numbers for parasitoid establishment. Ryan (1987) listed more social and economic reasons for failure of biological control including perceived slow returns (3-60 yr), difficulty in evaluating and establishing success, and the impression that biological control does not work, all which reduce the political will to financially support such programs. Currently, there appears to be no relation between the establishment of parasitoids and rate of success of projects (Hall et al. 1980) and thus, there are no general characteristics which distinguish a potentially successful or unsuccessful project.

In general, the data suggest that the underlying principle which results in successful biological control is that of local extinction rather than population regulation as previously thought (Luck 1990). Reviews of past biological 'successes' such as the winter moth (Murdoch et al. 1985; Roland 1988) and larch sawfly support this stochastic non-equilibrium view of the interaction. Introduced parasitoids tend to eliminate the pest from localized patches but fail to cause complete extinction because of the heteroge- nous nature of the forest (Caltagirone 1981). Simulation models show that a parasitoid can have either a high attack rate (and reduce pest numbers) or an aggregated attack pattern (which results in a stable interaction), but never both (Luck 1990). This view of the 'ideal parasitoid' tends to be strengthened as we continue to learn more about these systems.

\section{Augmentation}

Augmentation refers to the increase in already established parasitoid or predator numbers at a critical time (i.e. when the host is susceptible) (Mills 1990). This can be achieved either through releasing natural enemies or by manipulating the environment so that their impact will be improved. As noted earlier, the distinction between environmental augmentation and conservation is often hazy, but for present purposes, augmentation will be used only in those situations where natural enemy populations are actually promoted rather than simply maintained.

\section{Release}

Parasitoid release is usually concerned with localized increases of native species (Mills 1990). These can be of two types; inoculative, where the release usually occurs at the beginning of the season and the progeny have an effect on the pest (Nordlund 1984) and inundative, where the parasitoids are released for an immediate, non-sustaining effect, much like a biopesticide and the progeny have little or no effect (Mills 1990).

Inoculative: Examples of inoculative releases are rare in the forestry literature because a large majority of the pests complete only one generation per year and thus, are susceptible to attack for a very short time $(<4 \mathrm{wk})$. The earliest record of inoculative-type releases are for the European spruce sawfly where over 882 million parasitoids, Dahlbominus fuscipennis (Zett.) [Hymenoptera: Eulophidae], were released between 19341948 in Canada (Wallace and Smith, in press). While these releases were primarily to introduce and establish the parasitoid, the fact that they continued over a number of years in the same location suggests that they functioned as inoculative releases. Inoculative releases of 
native parasitoid species were also made against the gypsy moth during the 1970s in Pennsylvania (Reardon 1981). These releases resulted in a $2 \%$ increase in parasitism but not sufficient to reduce pest populations economically.

Inundative: Inundative releases have had only recently a high profile in suppressing forest pests. Early work in Europe demonstrated that pests in forest stands could be reduced by transporting a native ant in the Formica rufa group to stands with low predator populations (Youngs 1983). Finnegan (1975) suggested that this approach should be tried in Canada, but recognized the difficulty in conducting such manipulations in our relatively unmanaged forests.

Records of inundative releases appear in the Communist countries (primarily the People's Republic of China and the Commonwealth of Independent States) from 1895 to the present (Wallace and Smith, in press). Worldwide, 43 species of natural enemies are used in inundative releases against over 25 pest species in nine orders (King et al. 1985). Commercial rearing of these natural enemies in the USA is conducted by 62 producers, and 2-3 producers in Canada. Primary species being reared include the parasitoids, Encarsia spp. and Trichogramma spp. and the predators, phytoseid mites and Chrysopa spp. Artificial diets for mass production are currently available for nine of these species with 22 species being reared in vivo (King et al. 1985).

No parasitoids or predators are commercially released against forest pests. Parasitoids have been used, however, in forest situations, primarily in the forestry-based countries, Canada, USA, the former USSR, and the People's Republic of China. These parasitoids have come from four families; Tachinidae, Braconidae, Scelionidae, and Trichogrammatidae. The use of Trichogramma spp. is undoubtedly the most prevalent of all the groups with releases occurring in over seven countries on over 8 million ha of crops; approximately 1 million of these occurring in forests (Knipling 1980).

During 1950-1960, releases of the scelionid egg parasitoid [Telenomus terebrans (Ratzeburg)] [Hymenoptera: Sce- lionidae] were conducted in the former USSR against Dendrolimus sibiricus Tschetw. [Lepidoptera: Lasiocampidae] (Orr 1988). No information is available as to their success (Wallace and Smith, in press). More recently, inundative releases of the braconid, Cotesia melanoscelus (Ratz.) [Hymenoptera: Braconidae], have been made against the gypsy moth in Maryland (Hoy 1975; Kolochy-Hirsch et al. 1988; Weseloh and Anderson 1975). Release rates of 12000 females $\mathrm{ha}^{-1}$ led to increased parasitism of $10 \%$ over control plots but with no associated decline in gypsy moth populations. An integrated approach using five different parasitoids, three in inundative releases, was also attempted in Virginia against the gypsy moth with no success (Nealis and Wallace 1991; Ticehurst and Finley 1988).

The largest attempt at using inundative releases against a forest pest is that of the egg parasitoid, Trichogramma minutum Riley [Hymenoptera; Trichogrammatidae], against the spruce budworm in North America. Cage studies began in Québec during the early 1970s (Wallace and Smith, in press), followed by small field trials in Maine during the late 1970s (Houseweart et al. 1984), and a major rearing and release program in Ontario during the 1980s (Smith et al. 1990). At the end of Phase I of the Ontario program (1987), it was shown that two aerial releases of 12 million females ha $^{-1}$ release $^{-1}, 1 \mathrm{wk}$ apart and initiated at the beginning of the budworm's oviposition period, would result in egg parasitism of ca. $70 \%$ and subsequent larval reductions of about $80 \%$. While this level of control was considered economically acceptable, the high cost of production currently makes the commercial use of this approach unfeasible.

\section{Environmental manipulation}

It is well documented that the spatial structure of natural enemy guilds shifts according to habitat changes (Force 1970; Miller 1983; Miller and Ehler 1990). These shifts can be the result of either indirect manipulations of the habitat or of direct intervention in the environment.

Indirect: In forestry, researchers generally consider that increased levels of parasitism are associated with higher stand 
diversity (either vertical or horizontal) (Jennings and Houseweart 1983; Nealis 1991b; Torgersen et al. 1990). Unfortunately, most habitat changes and their effect on insect diversity have been documented in agricultural rather than in forestry systems. Nordlund (1984) showed that by increasing plant diversity in pecan vineyards (e.g. planting crown vetch), ladybird beetles could be augmented to reduce aphid populations. No such work has been conducted in forestry although Syme's (1977) studies on wild carrot and its effect on parasitoids of the European pine shoot moth initiated some interest in habitat manipulation in Nova Scotia during the early 1980s (Hulme and Kelleher 1984). Finnegan (1975) also proposed the removal of trees and the addition of woody debris in budworm-infested forests to augment predaceous ants although this was never conducted.

The effect of increasing a plant's resistance to insect pests on the associated parasitoid guild of the pest (tri-trophic interaction) has also been examined in agricultural systems but not in forestry (Altieri et al. 1977; Bergman and Tingey 1979; Herzog and Funderburk 1985). In forestry, Thorpe and Caudle (1938) reported that a parasitoid of the European pine shoot moth was attracted to the plant upon which its host fed, however, no experimental manipulations were ever conducted to quantify the impact of the host plant on natural enemy abundance. This remains an area of research as increased emphasis is placed on genetically improved seed stock for regeneration.

Direct: Direct environmental manipulation encompasses a wide spectrum of activities ranging from the use of semiochemicals (specifically kairomones used by a parasitoid to locate its host) to the provisioning of hosts, food, shelter or reproductive sites in the habitat.

Kairomones, such as the pheromones released by female hosts and volatiles from host scales, are often used as cues by parasitoids to locate their hosts (Lewis and Martin 1990; Lewis and Nordlund 1985; Lewis et al. 1975). These can function as either long or close range signals to improve levels of parasitism (Gross 1986). Herard et al. (1988) proposed their use prior to the release of laboratory- reared parasitoids as a means of imprinting the host image (smell) and thereby, improving parasitism. Kairomones are known to increase habitat and host-habitat finding, host location and acceptance, parasitoid foraging and retention in the release area, and parasitoid longevity and fecundity (Greany et al. 1984; Nordlund 1984). Zaborski et al. (1987) demonstrated the increased searching behaviour of Trichogramma minutum when exposed to the scales of its host, spruce budworm. When these results were tested under field conditions by exposing the parasitoids to host kairomones prior to release, however, no significant increases in egg parasitism were observed (Jennings and Jones 1986).

The provisioning of hosts or food has also been studied in agricultural systems where sugar sprays have been applied to crops to increase activity by Trichogramma spp. (Knipling 1980) and non-crop plants and target host eggs have been provided to increase chrysopid larvae in fields; however, no such work has been conducted in forestry. Similarly, shelter and reproductive sites, such as nest boxes for avian predators, although tested to a limited extent in European forests, have not been investigated in North America (Nealis 1991b).

\section{APPLICATION TO CANADIAN FORESTRY}

As discussed in the previous sections, biological control in Canada has been based predominantly on introductions of exotic natural enemies. This approach undoubtedly has some relation to the nature of forest protection. In almost all regions, forest pest control is the responsibility of the provincial government as the land-owner and this is supported through taxes from the forest industry (who leases the land). The Canadian federal government also provides long-term support for pest control and research from the taxes associated with major exports of wood and wood products. Thus, the public land-owner in Canada (the government) has been more willing to invest in those long-term biological or ecological studies necessary to implement successful introduction programs than might otherwise be the case if the land was owned privately. 
The relatively low value of the original Canadian forest compared to the intensively managed agricultural crops and the recent forest stands means that annual investments in pest control, while longterm, were kept to a minimum. The extensive nature of pest outbreaks in such forests, often covering $100 \mathrm{000s}$ ha or more of inaccessible area, also limited the degree of active intervention that could be carried out in the relatively short period of biological vulnerability (Nealis and Wallace 1991). Finally, in the first 60 years of this century, Canada's major pest problems were from the accidental introduction of exotic pests which had no known natural enemies. Thus, long-term, low cost solutions which could reestablish old host-parasitoid associations and be self-sustaining were supported over the years. It is only in recent years, as $60-80 \%$ of our pest problems arise from native species (Hokkanen and Pimentel 1989) and the technology for mass production of natural enemies has advanced that we have shifted our emphasis away from introduction towards augmentation and conservation.

The relatively high degree of success that has been observed with Canadian introductions not only results from an established, well-supported network of researchers over the years, but also because of the nature of the forest environment. Hall et al. (1980) reported a much higher success rate for introductions attempted in intermediate environments $(72 \%)$ than in unstable agricultural systems (47\%). Similarly, Nordlund (1984) noted that the probability of success increased as the stability of the environment increased. Although we still lack a consistent theory to explain why introductions have been successful, some of the major successes have occurred in Canada against forest insect pests.

\section{CURRENT STATUS OF BIOLOGICAL CONTROL IN FORESTRY}

In general, successful biological control of pests has occurred wherever attempts have been made (Ryan 1987). In fact, the major limiting factor to success appears to be the amount of funds invested (Mills 1990). This lack of funds also has made it difficult to evaluate the past programs and undoubtedly prevented us from understanding completely what are the necessary components of a successful program.

Few guidelines are available for managers on how much to invest in biological control programs. Historically, Canada has invested significant amounts, perhaps more so than most countries, but in these days of diminishing resources, such projects must be constantly reassessed. This is particularly true in view of the fact that the number of successes has declined over time (Greathead 1986).

In order for a continued program to be feasible, Harris (1979) has suggested that, at least for biological control of weeds, the cost of the program should be less than 10 times the loss from the pest and the probability of success for the proposed control in a given year. Similar estimates were made by Cock (1986) and in general, the successful programs have documented costs well within this range. Successful biological control programs have more than covered their costs and for those that have been unsuccessful like the spruce budworm, the costs have represented only a marginal amount of the damage caused by the pest. In almost all cases, it has paid to invest in biological control for control of forest pests.

Most of the remaining pests in Canada are native or are exotics which have not been successfully controlled with introductions (Mills 1990). The literature suggests that there are a number of natural enemy complexes available for controlling such pests. Considerable information can be obtained on these guilds through publications of the Commonwealth Agricultural Bureaux, Forestry Canada, and Forest Insect and Disease Survey as well as extensive European documentation (Nealis 1991b). As was recommended by Hulme and Kelleher (1984), researchers in Forestry Canada are now putting more emphasis on obtaining information about the population dynamics of pests such as the spruce budworm to identify key regulating factors and develop truly integrated management programs. 


\section{Conservation}

Currently, very little work is being done on the conservation of natural enemies although it represents a productive area for future research. One study in jack pine plantations near Gogama, Ontario, is examining the effect of horizontal spacing of trees during reforestation and its effect on the white pine weevil (Pissodes strobi Beck) [Coleoptera: Pissodinae] and its natural enemy complex (Smith 1992). This work suggests that stand spacing has little effect on either small mammal or bird predation but may be important in the associated parasitoid complex and overwintering survival. Such findings have implications for forest management suggesting that different planting strategies conserve equally the natural enemy complex of white pine weevil.

There is a strong need to understand and predict the effects of natural enemies of pest species (Nealis 1991b). An understanding of how habitat conditions influence parasitoid guilds and pest population dynamics will be an essential part of future management of forest pests (Mills 1990). This area must receive increased emphasis in Canada if we are truly going to integrate pest and forest management for successful programs.

\section{Introduction}

Our previous success with introductions suggests that we are continuing to implement this approach although our emphasis on the type of species used and our objectives are shifting. Efforts are now aimed at prolonging endemic phases of the pest rather than reducing the epidemic outbreak (Nealis 1991b). Species being introduced are from either nonoutbreak insect populations or insects which are no longer considered pests in their country of origin (Mills 1990). The goal is local extinction (Murdoch et al. 1985) with a better understanding of the systematics and behavioural ecology of the natural enemy (Luck 1990). Increased effort is placed on using Diptera rather than Hymenoptera because of their better record of success (Munroe 1971).

A good example of this new approach is the current investigation by Forestry Canada (V. Nealis-Ontario Region; W.
Quednau-Québec Region) to introduce Ceranthia samarensis (Villeneuve) [Diptera: Tachinidae], a tachinid parasitoid found in low density host populations in Europe, for control of the gypsy moth (Nealis and Wallace 1991). This parasitoid was collected from trap hosts placed out in low density populations of the European gypsy moth. Trap hosts are often necessary for collections in these low host populations. (Myers et al. (1989) have even suggested that the pest be augmented to see which natural enemy responds in order to select the most appropriate for maintaining these endemic phases). The $C$. samarensis pupae were shipped to Canada for release, but difficulties in rearing may influence the future outcome of this project. Successful rearing of such dipteran parasitoids remains a challenge for implementing this approach in the future.

Considerable interest is still being directed at how these introductions should be approached and what constitutes a 'good' natural enemy (Waage 1990). In the search for the perfect natural enemy, two approaches are considered; reductionist and holistic. The first implies that individual species should be examined in great biological detail and then the 'best' one selected for use. Support for this approach comes from various perspectives (Greathead 1986; Hall and Ehler 1979; Myers et al. 1989; PschornWalcher 1977). Usually these authors have pointed out the previous success rate of single species introductions $(68 \%$ of the attempts) and the stability of complex forest systems. To carry this to the extreme, there is also interest to genetically improve selected natural enemies through selection and DNA engineering in an effort to create the 'super' parasitoid (Beckendorf and Hoy 1985).

The holistic approach to introductions suggests that the whole guild of natural enemies (and hyperparasitoids) should be considered and that tradeoffs in good characteristics (eg. fecundity and searching rate or intrinsic and extrinsic superiority) should be made before several of the guild are selected (Roland 1988; Waage 1990). Supporters of this approach include Mills (1990), Hassell (1978), and Huffaker (1971). The jury is still out on 
which approach is best, but the records suggest that we have nothing to lose in continued attempts at multiple introductions.

Introductions are now also being attempted to develop new associations rather than to try and reestablish a traditional old association. The current work described by Nealis and Wallace (1991) utilizing Apanteles murinanae (Capek \& Zwiëlfer) [Hymenoptera: Braconidae], a parasitoid of the European budworm, against the spruce budworm in Canada makes use of this approach. Releases of 250 females are now being attempted in low density budworm populations in Québec to see if this new addition to the parasitoid guild can help reduce populations of the spruce budworm.

It is generally acknowledged that for improved chances of success, introductions should be made with at least 500 females per release (Greathead 1986; Quednau 1990; Reeks and Cameron 1971). These natural enemies should be collected from as broad a geographical area as possible to improve their genetic heterozygocity (Mackauer 1976) and be introduced without hyperparasitoids (Hulme and Kelleher 1984). These authors have also proposed that the search area for identifying desirable natural enemies be broadened beyond that of Europe alone. When more than one species is to be introduced, it has been suggested that the competitively inferior species be brought in first to reduce competition and improve the chance of establishment (Cock 1986; Pschorn-Walcher 1977). Success or failure should be evident within $3 \mathrm{yr}$ of the initial introduction (Clausen 1951; Quednau 1990).

\section{Augmentation}

Perhaps of the three approaches, augmentation is the one which is changing most rapidly, in particular, inundative releases. Mills (1990) identified this as the area of future emphasis for biological control. Recent technological advances in mass rearing and the public pressure to find alternatives to chemical insecticides have certainly improved the chances of this approach becoming economically feasible in the near future. The fact that it takes advantage of an approach to pest control similar to previous insecticide applications makes its acceptance by pest control operators more certain.

Unlike introductions to establish selfsustaining species, augmentation requires a constant supply of large numbers of natural enemies and this ensures commercial interest. Research now focuses on improving the commercial production of selected natural enemies to ensure large numbers, but, more importantly, a good 'quality' product. The Ontario project on Trichogramma spp. against the spruce budworm, for example, recently initiated Phase II (1989) in which Ciba-Geigy Canada, Inc. took an active lead in developing the technology for mass production. This project has a major emphasis on identifying high quality parasitoids and establishing a protocol for their selection and maintenance as well as for developing other potential markets outside spruce budworm.

Questions currently being addressed in augmentative releases include where is the optimal location(s) for collection; should the stocks be replenished annually or at longer intervals; what is the impact on quality of short- and long-term rearing and storage on facticious or artificial hosts; can the material or processes be patented to protect the industry's investment; is there an appropriate registration system for use of the material; how should the material be released; can or should the material be genetically manipulated; and can semiochemicals or other methods be used to improve its efficacy (Beckendorf and Hoy 1985; Cock 1986; Greany et al. 1984; Knipling 1980; Lewis and Nordlund 1985; Mills 1990). The future of augmentation rests in whether we can be guaranteed of proper field assessments of its efficacy and its future integration into other aspects of forest pest management.

At the moment, inundative release of natural enemies is expensive. King et al. (1985) identified costs as high as \$7800 $\mathrm{ha}^{-1}$. The higher application rates that will undoubtedly be required in traditional forest applications will not provide much opportunity for reduced costs. This factor, combined with the relatively low value of the original forest product, will curtail the rapid expansion of the augmentative 
approach in unmanaged stands. The potential for parasitoid augmentation, however, remains relatively high against pests in the new forest (Smith 1990). Many of these new pests are cryptic and have no current means of control (eg. the spruce budmoth, Zeiraphera canadensis Ratzb.) [Lepidoptera: Olethreutidae] . Their impact is also significantly greater than historical pests because they attack trees in the new forest where regeneration investments must be protected. Thus, as the management of the forest intensifies, augmentation will become a larger factor in biological control of the pests.

\section{THE FUTURE}

The previous work suggests that we have been very successful in attempts to control forest insect pests through biological control, particularly in Canada where the major emphasis has been directed. There have been a number of successes documented against defoliating insects including the winter moth, European spruce sawfly, Mountain ash sawfly, larch casebearer, and larch sawfly. With a few exceptions, the remaining problems caused by defoliating species are mostly native (e.g. spruce budworm) and current studies to identify key mortality factors which regulate the dynamics of these species may help to provide biological control solutions to this problem in the future.

Few attempts have been made against other forest pest guilds, although as forest regeneration and values increase, these will become the new areas for biological control. Where biological control has been attempted against cryptic guilds such as the tip and shoot insects, they have tended to be successful (e.g. European pine shoot moth). Except for some small trials using nematodes against root weevils, attempts at biological control of seed and cone insects or insects attacking the roots of tree have been negligible. One success using a parasitoid against the woodboring Sirex spp. in Tasmania has been reported (Taylor 1978); however, our attempts in Canada at releasing predators against bark adelgids have failed and few attempts have been made against the bark beetles (Miller et al. 1987).
The future of biological control in forestry should continue to remain bright. Increased emphasis will persist in this area both because of our past successes and the increased pressure from society for perceived 'non-interventions' in government-owned areas. The public will demand more specific control methods which are considered minimally disruptive to these 'natural' ecosystems. The cost:benefit relationship for this approach to pest control has always been good and should continue to be better than synthesized insecticides.

The obstacles to overcome in future biocontrol programs will be two-fold: one at the government level and one at the commercial level. Governments, both provincial and federal, must continue to recognize the value of long-term biological studies, despite their own limited terms, and continue to support this type of research. Our past successes are the result of this support and it must continue if we are going to make further advances. The second aspect to the future of biological control is that of the commercial producer. The future avenues must be viewed from the perspective of product reliability, patentability, registerability and cost-effectiveness (Jutsum 1988). Just as in the production and commercialization of pathogens for control of insect pests (e.g. Bt), the producers of biological control agents will have to address these issues in light of expected returns. If these hurdles are met, then the future of biological control in forestry would indeed look promising.

\section{REFERENCES}

Altieri, M.A., and W.H. Whitcomb. 1979. The potential use of weeds in the manipulation of beneficial insects. HortScience 14: 1218.

Altieri, M.A., A. van Schoonhoven, and J. Doll. 1977. The ecological role of weeds in insect pest management systems: a review illustrated with bean (Phaseolus vulgaris L.) cropping systems. PANS (Pest Artic. New Summ.) 23: 185-206.

Anonymous. 1983. Biological control of insect pests. Environ. Canada, Can. For. Serv. Fact Sheet. 4 pp.

Askew, R.R. 1971. Parasitic insects. Heinemann, London. 316 pp. 
Beckendorf, S.K., and M.A. Hoy. 1985. Genetic improvement of arthropod natural enemies through selection, hybridization or genetic engineering techniques. Pages 167189 in M.A. Hoy and D.C. Herzog (eds.), Biological control in agricultural IPM Systems. Academic Press, London.

Beirne, B.P. 1967. Pest Management. International textbook Co., London.

Bergman, J.M., and W.M. Tingey. 1979. Aspects of interaction between plant genotypes and biological control. ESA Bull. 25: 275-279.

Caltagirone, L.E. 1981. Landmark examples in classical biological control. Ann. Rev. Entomol. 26: 213-232.

Clausen, C.P. 1951. The time factor in biological control. J. Econ. Entomol. 44: 1-9.

Cock, M.J.W. 1986. Requirements for biological control: an ecological perspective. Biocontrol News and Information 7: 7-16.

Dahlsten, D.L., and N.J. Mills. 1990. Biological control of forest insects. T.W. Fisher (ed.), Principles and application of biological control. California University Press, Los Angeles. (in press).

DeBach, P. 1964. Successes, trends, and future possibilities. Pages 673-712 in P. DeBach (ed.), Biological control of insect pests and weeds. Reinhold Publ. Co., New York.

Drooz, A.T., A.E. Bustillo, G.F. Fedde, and V.H. Fedde. 1977. North American egg parasite successfully controls a different host genus in South America. Science (Wash. DC) 197: 390-391.

Finnegan, R.J. 1975. Introduction of a predacious red wood ant Formica lugubris (Hymenoptera: Formicidae) from Italy to eastern Canada. Can. Entomol. 107: 1271-1274.

Flanders, S.E. 1971. Single factor mortality, the essence of biological control, and its validation, in the field. Can. Entomol. 103: 1351-1362.

Force, D.C. 1970. Competition among four Hymenopterous parasites of an endemic insect host. Ann. Entomol. Soc. Am. 63: 1675-1688.

Fuester, R.W., F. Gruber, J.J. Drea Jr., and H. Hoyer. 1988. Parasites of Lymantria dispar (Lepidoptera: Lymantriidae) in France and their relation to a biological control program. Acta Oecol. Oecol. Appl. 9: 385-402.

Graham, S.A. 1931. The present status of the larch sawfly (Lygaeonematus erichsonii Hartig) in Canada, with special reference to its specific parasite, Mesoleius tenthredinis Morley. Can. Entomol. 63: 99-102.

Greany P.D., S.B. Vinson, and W.J. Lewis. 1984. Insect parasitoids: Finding new opportunities for biological control. BioScience 34: 690-696.
Greathead, D.J. 1986. Parasitoids in classical biological control. Pages 290-319 in J. Waage and D. Greathead (eds.), Insect parasitoids. Academic Press, London.

Greathead, D.J. 1989. Biological control as an introduction phenomenon: a preliminary examination of programmes against Homoptera. Entomologist 108: 28-37.

Gross, H.R., Jr. 1986. Conservation and enhancement of entomophagous insects- a perspective. J. Entomol. Sci. 22: 97-105.

Hall, R.W., and L.E. Ehler. 1979. Rate of establishment of natural enemies in classical biological control. ESA Bull. 25: 280-282.

Hall, R.W., L.E. Ehler, and B. Bisabri-Ershadi. 1980. Rate of success in classical biological control of arthropods. ESA Bull. 26: 111-114.

Harris, P. 1979. Cost of biological control of weeds by insects in Canada. Weed Sci. 27: 242-250.

Hassan S.A., F. Bigler, H. Bogenschutz, E. Boller, J. Brun, P. Chiverton, P. Edwards, F. Mansour, E. Naton, P.A. Oomen, W.P.J. Overmeer, L. Polgar, W. Rieckmann, L. Samsoe-Petersen, A. Staubli, G. Sterk, K. Tavares, J.J. Tuset, G. Viggiani, and A.G. Vivas. 1987. Results of the third joint pesticide testing programme by the IOBC/ WPRS-working group "Pesticides and beneficial organisms". J. Appl. Entomol. 103: 92-107.

Hassell, M.P. 1978. The dynamics of arthropod predator-prey systems. Princeton University Press, Princeton, NJ. 2:37 pp.

Herard, F., M.A. Keller, W.J. Lewis, and J.H. Tumlinson. 1988. Beneficial arthropod behavior mediated by airborne semiochemicals. IV. Influence of host diet on hostoriented flight chamber responses of $\mathrm{Mi}$ croplitis demolitor Wilkinson. J. Chem. Ecol. 14: 1597-1606.

Herzog D.C., and J.E. Funderburk. 1985. Plant resistance and cultural practice interactions with biological control. Pages 67-89 in M.A. Hoy and D.C. Herzog (eds.), Biological control in agricultural IPM systems. Academic Press, London.

Hokkanen, H.M.T., and D. Pimentel. 1984. New approach for selecting biological control agents. Can. Entomol. 116: 1109-1121.

Hokkanen, H.M.T., and D. Pimentel. 1989. New associations in biological control: theory and practice. Can. Entomol. 121: 829-840.

Houseweart, M.W., D.T. Jennings, and R.K. Lawrence. 1984. Field releases of Trichogramma minutum (Hymenoptera: Trichogrammatidae) for suppression of epidemic spruce budworm, Choristoneura fumiferana (Lepidoptera: Tortricidae), egg populations in Maine. Can. Entomol. 116: 1357-1366. 
Hoy, M.A. 1975. Forest and laboratory evaluations of hybridized Apanteles melanoscelus (Hymenoptera: Braconidae), a parasitoid of Porthetria dispar (Lepidoptera: Lymantriidae). Entomophaga 20: 261-268.

Huffaker, C.B. (ed.) 1971. Biological control. Plenum Press, New York. 511 pp.

Huffaker, C.B., and C.E. Kennett. 1969. Some aspects of assessing efficiency of natural enemies. Can. Entomol. 101: 425-447.

Hull, L.A., and E.H. Beers. 1985. Ecological selectivity: modifying chemical control practices to preserve natural enemies. Pages 103-123 in M.A. Hoy and D.C. Herzog (eds.), Biological control in agricultural IPM systems. Academic Press, London.

Hulme, M.A. 1988. The recent Canadian record in applied biological control of forest insect pests. For. Chron. 64: 27-31.

Hulme, M.A., and J.S. Kelleher (eds.). 1984. Biological control programmes against insects and weeds in Canada 1969-1980. Commonwealth Agricultural Bureaux, Slough, UK. $410 \mathrm{pp}$.

Jennings, D.T., and R.L. Jones. 1986. Field tests of kairomones to increase parasitism of spruce budworm (Lepidoptera: Tortricidae) eggs by Trichogramma spp. (Hymenoptera: Trichogrammatidae). Great Lakes Entomol. 19: 185-189.

Jennings, D.T., and M.W. Houseweart. 1983. Parasitism of spruce budworm (Lepidoptera: Tortricidae) eggs by Trichogramma minutum and absence of overwintering parasitoids. Environ. Entomol. 12: 535-540.

Juillet, J.A. 1960. Immature stages, life histories, and behaviour of two hymenopterous parasites of the European pine shoot moth, Rhyacionia buoliana (Schiff.) (Lepidoptera: Olethreutidae). Can. Entomol. 92: 342-346.

Jutsum, A.R. 1988. Commercial application of biological control: status and prospects. Philos. Bio. Sci. R. Soc. Lond. B. Biol. Sci. 318: 357-373.

King, E.G., K.R. Hopper, and J.E. Powell. 1985. Analysis of systems for biological control of crop arthropod pests in the U.S. by augmentation of predators and parasites. Pages 201-229 in M.A. Hoy and D.C. Herzog (eds.), Biological control in agricultural IPM systems. Academic Press, London.

Knipling, E.F. 1980. Augumentation of entomophagous arthropods. Pages 354-363 in Biological control in crop production. Beltsville Symposia in Agricultural Research. Allanheld, Osmun Pub., Granada, London.

Kolochy-Hirsch, D.M., R.C. Reardon, K.W. Thorpe, and M.J. Raupp. 1988. Evaluating the impact of sequential releases of Cotesia melanoscela (Hymenoptera: Braconidae) on Lymantria dispar (Lepidoptera: Lymantriidae). Environ. Entomol. 17: 403-408.
Lewis, W.J., and W.R. Martin, Jr. 1990. Semiochemicals for use with parasitoids: status and future. J. Chem. Ecol. 16: 30673089.

Lewis, W.J., and D. A. Nordlund. 1985. Behavior-modifying chemicals to enhance natural enemy effectiveness. Pages 89-103 in M.A. Hoy and D.C. Herzog (eds.), Biological control in agricultural IPM systems. Academic Press, London.

Lewis, W.J., R.L. Jones, D.A. Nordlund, and A.N. Sparks. 1975. Kairomones and their use for management of entomophagous insects: I. Evaluation for increasing rates of parasitization by Trichogramma spp. in the field. J. Chem. Ecol. 1: 343-347.

Luck, R.F. 1990. Evaluation of natural enemies for biological control: a behavioral approach. Tree 5: 196-199.

Mackauer, M. 1976. Genetic problems in the production of biological control agents. Annu. Rev. Entomol. 21: 369-385.

McClure, M.S. 1978. Resurgence of the scale, Florinia externa (Homoptera: Diaspididae) on hemlock following insecticide application. Environ. Entomol. 6: 480-484.

McGugan, B.M., and H.C. Coppel. 1962. Biological control of forest insects 1910-1958. Pages 35-127 in A review of the biological control attempts against insects and weeds in Canada. Commonw. Inst. Biol. Control Tech. Commun. 2. Slough, UK.

Miller, J.C. 1983. Ecological relationships among parasites and the practice of biological control. Environ. Entomol. 12: 620624.

Miller, J.C. and L.E. Ehler. 1990. The concept of parasitoid guild and its relevance to biological control. Pages 159-169 in $\mathrm{M}$. Mackauer, L. E. Ehler, and J. Roland (eds.), Critical Issues in Biological control. Intercept, Andover, Hants.

Miller, M.C., J.C. Moser, M. McGregor, J.-C. Gregoire, M. Baisier, D.L. Dahlsten, and R.A. Werner. 1987. Potential for biological control of native North American Dendroctonus beetles (Coleoptera: Scolytidae). Ann. Entomol. Soc. Am. 80: 417-428.

Miller, W.E. 1967. The European pine shoot moth - ecology and control in the Lake States. For. Sci. Monogr. 14. 72 pp.

Mills, N.J. 1983. Possibilities for the biological control of Choristoneura fumiferana $(\mathrm{Cle}$ mens) using natural enemies from Europe. Biocontrol News and Information 4: 103-125.

Mills, N.J. 1990. Biological control, a century of pest management. Bull. Entomol. Res. 80: 359-362. 
Munroe, E.G. 1971. Status and potential of biological control in Canada 1959-1968. Pages 213-255 in Biological control programmes against insects and weeds in Canada 1959-1968. Commonw. Inst. Biol. Control Tech. Commun. 2. Slough, UK.

Murdoch, W.W., J. Chesson, and P.L. Chesson. 1985. Biological control in theory and practice. Am. Nat. 125: 344-366.

Myers, J.H., C. Higgins, and E. Kovacs. 1989. How many insect species are necessary for the biological control of insects? Environ. Entomol. 18: 541-547.

Nealis, V. 1991a. Parasitism in sustained and collapsing populations of the jack pine budworm, Choristoneura pinus pinus Free. (Lepidoptera: Tortricidae), in Ontario 19851987. Can. Entomol. 123: 1065-1075.

Nealis, V. 1991b. Natural enemies and forest pest management. For. Chron. 67: 500505.

Nealis, V., and K. van Frankenhuyzen. 1990. Interactions between Bacillus thuringiensis Berliner and Apanteles fumiferanae Vier. (Hymenoptera: Braconidae), a parasitoid of the spruce budworm, Choristoneura fumiferana (Clem.) (Lepidoptera: Tortricidae). Can. Entomol. 122: 585-594.

Nealis, V.G., and D.R. Wallace. 1991. Biological control of forest pests by insect parasitoids. Pages 15-22 in A.S. McClay (ed.), Proc. Workshop on Biological Control of Pests in Canada. Alberta Environ. Ctr., Vegerville, Alberta.

Nielson, M.M., R. Martineau, and A.H. Rose. 1971. Diprion hercyniae (Hartig), European spruce sawfly (Hymenoptera: Diprionidae). Pages 136-144 in Biological control programmes against insects and weeds in Canada 1959-1968. Commonw. Inst. Biol. Control Tech. commun. 4, Slough, UK.

Nordlund, D.A. 1984. Biological control with entomophagous insects. J. Ga. Entomol. Soc. $2^{\text {nd }}$ Suppl. 19: 14-27.

Orr, D.B. 1988. Scelionid wasps as biological control agents: a review. Fla. Entomol. 71: 506-528.

Pointing, P.J., and G.W. Green. 1962. A review of the history and biology of the European pine shoot moth, Rhyacionia buoliana (Schiff.) (Lepidoptera: Olethreutidae) in Ontario. Proc. Entomol. Soc. Ont. 92: 58-69.

Pschorn-Walcher, H. 1977. Biological control of forest insects. Annu. Rev. Entomol. 22: 1-22.

Quednau, F.W. 1990. Introduction, permanent establishment, and dispersal in eastern Canada of Oleicampe geniculatae Quednau \& Lim (Hymenoptera: Ichneumonidae), an important biological control agent of the mountain ash sawfly, Pristiphora geniculata (Hartig) (Hymenoptera: Tenthredinidae). Can. Entomol 122: 921-934.
Reardon, R.C. 1981. Alternative controls. 6.1 Parasites. Pages 299-423 in C.C. Doane and M.L. McManus. (eds.), The gypsy moth: research toward integrated pest management. USDA For. Serv. Tech. Bull. 1584.

Reeks, W.A., and J.M. Cameron. 1971. Current approaches to biological control of forest insects 1959-1968. Pages 105-113 in Biological control programmes against insects and weeds in Canada 1959-1968. Commonw. Inst. Biol. Control Tech. Commun. 4. Slough, UK.

Roland, J. 1988. Decline in winter moth populations in North America: direct versus indirect effect of introduced parasites. J. Animal Ecol. 57: 523-531.

Rosenheim, J.A., and M.A. Hoy. 1988. Genetic improvement of a parasitoid biological control agent: artificial selection for insecticide resistance in Aphytis melinus (Hymenoptera: Aphelinidae). J. Econ. Entomol. 81: 1539-1550.

Ryan, R.B. 1987. Classical biological control: an overview. J. For. 85: 29-31.

Sawyer, R.C. 1990. Monopolizing the insect trade: biological control in the USDA, 19511988. Agr. History 64: 271-286.

Smith, S.M. 1990. The greening of the forest: forest pest management into the $21^{\text {st }}$ century. Proc. Entomol. Soc. Ont. 121: 49-59.

Smith, S.M. 1992. Potential impact of white pine weevil on jack pine and management implications using stand manipulation. Proc. XIX Inter. Congr. Entomol. p. 431.

Smith, S.M., J.R. Carrow, and J.E. Laing (eds.). 1990. Inundative release of the egg parasitoid, Trichogramma minutum (Hymenoptera: Trichogrammatidae), against forest insect pests such as the spruce budworm, Choristoneura fumiferana (Lepidoptera: Tortricidae): The Ontario project 1982-1986. Mem. Entomol. Soc. Can. No. 153. 87 pp.

Sweetman, H.L. 1936. The biological control of insects. Comstock Pub. Co. Inc., Ithaca, New York. 461 pp.

Syme, P.D. 1977. Observations on the longevity and fecundity of Orgilus obscurator (Hymenoptera: Braconidae) and the effects of certain foods on longevity'. Can. Entomol. 109: 995-1000.

Taylor, K.L. 1978. Evaluation of the insect parasitoids of Sirex noctilio (Hymenoptera: Siricidae) in Tasmania. Oecologia 32: 1-10.

Thompson, W.R. 1930. The principles of biological control. Ann. Appl. Biol. 7: 306-388.

Thorpe, W.H., and H.B. Caudle. 1938. A study of the olfactory responses of insect parasites to the food plant of their host. Parasitology 30: 523-528.

Ticehurst, M., and S. Finley. 1988. An urban forest integrated pest management program for gypsy moth: an example. J. Arboric. 14: 172-175. 
Torgersen, T.R., R.R. Mason, and R.W. Campbell. 1990. Predation by birds and ants on two forest insect pests in the Pacific Northwest. Stud. Avian Biol. 13: 14-19.

Turnock, W.T., K.L. Taylor, D. Schroder, and D.L. Dahlsten. 1976. Biological control of pests of coniferous forests. Pages 289-311 in C.B. Huffaker and P.S. Messenger (eds.), Theory and practice of biological control. Academic Press, New York.

van Lenteren, J.C. 1983. Biological pest control: passing fashion or here to stay? Organorama 20: 3-9.

Waage, J. 1990. Ecological theory and the selection of biological control agents. Pages 135-157 in M. Mackauer, L.E. Ehler, and J. Roland (eds.), Critical issues in biological control. Intercept, Andover, Hants.

Waage, J., and D.J. Greathead. 1988. Biological control: challenges and opportunities. Philos. Trans. R. Soc. Lond. B Biol. Sci. 318: 111-128.
Waage, J., and M.P. Hassell. 1982. Parasitoids as biological control agents-a fundamental approach. Parasitology 84: 241-268.

Wallace, D.R., and S.M. Smith. 199X. Inundative releases in Control of forest insects in Canada. Volume 1. Part II. Pest Management Technology. (in press).

Weseloh, R.M., and J. Anderson. 1975. Inundative release of Apanteles melanoscelus against the gypsy moth. Environ. Entomol. 4: 33-36.

Youngs, L.C. 1983. Predaceous ants in biological control of insect pests of North American forests. ESA Bull. 29: 47-50.

Zaborski, E., P.E.A. Teal, and J.E. Laing. 1987. Kairomone-mediated host finding by spruce budworm egg parasite, Trichogramma minutum. J. Chem. Ecol. 13: 113-122. 